\title{
Isolation and purification of oligopeptides from Ruditapes philippinarum and its inhibition on the growth of DU-145 cells in vitro
}

\author{
ZUISU YANG, YUQIN ZHAO, HAIQIANG YAN, LV XU, GUOFANG DING, DI YU and YU SUN \\ School of Food Science and Pharmacy, Zhejiang Provincial Key Engineering Technology \\ Research Center of Marine Biomedical Products, Zhejiang Ocean University, \\ Zhoushan, Zhejiang 316000, P.R. China
}

Received January 18, 2014; Accepted August 22, 2014

DOI: $10.3892 / \mathrm{mmr} .2014 .2788$

\begin{abstract}
Ruditapes philippinarum is a member of the Veneridae family of marine bivalve molluscs. RPOI-1 (Ruditapes philippinarum oligopeptide) is a tetrapeptide that can be extracted from Ruditapes philippinarum by means of enzymolysis. This study showed that RPOI-1 strongly inhibits proliferation and induces apoptosis in DU-145 human prostate cancer cells. When cells were treated with varying concentrations of RPOI-1, significant inhibition of proliferation was detected by an MTT assay, and sub-G1 and G2/M phase cell cycle arrest was observed using flow cytometric (FCM) analysis. Furthermore, morphological changes characteristic of apoptosis and an increase in the proportion of apoptotic cells were observed using double sequential acridine orange/ethidium bromide staining, FCM analysis and transmission election microscopy. FCM studies showed that exposing DU-145 cells to 10, 20 and $30 \mathrm{mg} / \mathrm{ml}$ RPOI- 1 for $24 \mathrm{~h}$ increased the percentage of cells in the early-stages of apoptotis in a dose-dependent manner, with the numbers rising from $3.01 \%$ in the control group to $13.40 \%$ in the group treated with the highest dose.
\end{abstract}

\section{Introduction}

Ruditapes philippinarum, a member of the Veneridae family, is predominantly found along the coasts of the Philippines, Japan and China. It is an intertidal bivalve, which preferentially inhabits the inner bay. It has a high commercial value and is also an important aquaculture species in intertidal zones. RPOI-1 (Ruditapes philippinarum oligopeptide), is a water-soluble

Correspondence to: Miss. Zuisu Yang, School of Food Science and Pharmacy, Zhejiang Provincial Key Engineering Technology Research Center of Marine Biomedical Products, Zhejiang Ocean University, 1 Haida South Road, Lincheng Changzhi Island, Zhoushan, Zhejiang 316000, P.R. China

E-mail: yangzs87@163.com

Key words: Ruditapes philippinarum, oligopeptides, DU-145 cell line, apoptosis tetrapeptide that can be extracted from Ruditapes philippinarum by means of enzymolysis.

A number of studies have demonstrated that certain products from marine sources, including Sepia ink, Dolabella auricularia, Mactromeris polynyma and Halichondria okadai, have significant anticancer activity (1-4). Sepia ink oligopeptide (SIO) is an antitumor tripeptide that was first isolated from Sepia esculenta using enzymolysis. SIO was shown to significantly inhibit the proliferation of DU-145, PC-3 and LNCaP human prostate cancer (PCa) cells in a time- and dose-dependent manner (5). SIO has been shown to induce apoptosis in prostate cancer cell lines via activation of caspase-3 and elevation of the $\mathrm{Bax} / \mathrm{Bcl}-2$ ratio (5).

$\mathrm{PCa}$ is the most common type of malignancy worldwide and second only to lung cancer as the leading cause of cancer-related mortality (6). During the early stages of PCa, growth of prostatic epithelial cells is androgen-dependent. Therefore, hormone therapy has been an initial option with which to treat patients with PCa. However, tumor cells ultimately become androgen-independent, necessitating the development of different forms of treatment (7). Cytotoxic chemotherapy aims to kill cancer cells, but is not a targeted treatment, and therefore also affects healthy cells. Dox (doxorubicin) has potent and broad-spectrum therapeutic activity against PCa. Despite its effectiveness, the use of Dox is limited, as concentrations required to kill cancerous cells cannot be employed without causing systemic toxicity (8).

Numerous interventions have been tried in order to remove cancerous tissues, including surgery and chemotherapy, without universal success (9). In addition, many cancer drugs exhibit a relatively short clinical life span and become ineffective, due to the development of resistance. Furthermore, a number of potent drugs frequently cause serious side effects. Therefore, there is an urgent requirement to identify and develop novel anticancer agents that are safe and effective (10). The present study evaluated the anticancer activity and mechanisms of action of RPOI-1 against prostate cancer in a Du-145 PCa cell line. The objectives of the current study were to investigate the antiproliferative effects of RPOI-1 against DU-145 cells and to clarify whether apoptosis and cell-cycle arrest were involved in any observed anticancer activity. 


\section{Materials and methods}

Materials. Ruditapes philippinarum was collected from the Zhoushan coastal area. DU-145 human prostate cancer cells were obtained from the Cell Bank of the Chinese Academy of Science (Shanghai, China). The ultrafiltrate was applied to a column saturated in diethyaminoethyl (DEAE)-sepharose fast flow (FF; Amersham Pharmacia Biotech, Shanghai, China). The Ruditapes philippinarum peptide fraction was further purified using reverse-phase high performance liquid chromatography (HPLC) on a Primesphere C18 column (Phenomenex Co., Ltd., Shanghai, China). The degree of inhibition of proliferation of DU-145 cells was detected by a 3-(4,5-dimethylthiazol-2-yl)-2,5-diphenyltetrazolium bromide (MTT) assay (Hangzhou Haotian Biotechnology Co., Ltd., Hangzhou, China). F-12 medium, fetal bovine serum (FBS) and an Annexin V-fluorescein isothiocyanate (FITC) apoptosis detection kit were purchased from BD Biosciences (Franklin Lakes, NJ, USA). Other reagents were of analytical grade and produced in China.

Enzymatic hydrolysis. Ruditapes philippinarum tissues were homogenized and digested with protease at $45^{\circ} \mathrm{C}$ using trypsin [300 U/g, pH 7.0; solid-liquid ratio (w/v), 1:3] for $6 \mathrm{~h}$. Following enzymatic hydrolysis, the mixture was immediately heated to $95^{\circ} \mathrm{C}$ for $15 \mathrm{~min}$ in order to inactivate the enzyme. The hydrolysates were clarified by centrifugation at $8580 \mathrm{xg}$ for $20 \mathrm{~min}$ to remove the unhydrolyzed residue.

\section{Isolation and purification of the anticancer peptide}

Ultrafiltration. The Ruditapes philippinarum hydrolysate (RH) filtrate was filtered through a $3 \mathrm{kDa}$ molecular weight cut-off membrane (Amicon Ultra-15; Millipore, Billerica, MA, USA). It was then fractionated into two ranges of molecular weight ( $\mathrm{RH} 1>3 \mathrm{kDa}$ and $\mathrm{RH} 2 \leq 3 \mathrm{kDa}$ ). The respective permeates were lyophilized and their antitumor activity was measured using an MTT assay.

DEAE-sepharose FF ion exchange chromatography. The lyophilized fraction exhibiting the highest antitumor activity was dissolved in $0.05 \mathrm{mmol} / \mathrm{l} \mathrm{Tris} / \mathrm{HCl}$ buffer $(\mathrm{pH} \mathrm{7.4)}$ ) and applied to a DEAE-sepharose FF column $(115 \times 50 \mathrm{~mm})$, which had previously been equilibrated with the same buffer. The column was eluted with a linear gradient of $\mathrm{NaCl}$ concentrations in Tris/ $\mathrm{HCl}$ buffer from 0 to $1.0 \mathrm{~mol} / \mathrm{l}$. Fractions of $4 \mathrm{ml}$ were collected at a flow rate of $2 \mathrm{ml} / \mathrm{min}$. Chromatography was performed using an ÄKTA-explorer system (GE Healthcare, Little Chalfont, UK) and the elution peaks were monitored at $280 \mathrm{~nm}$.

Reverse-phase (RP)-HPLC. The fraction exhibiting the highest anticancer activity was further purified using reverse-phase HPLC on a Primesphere C18 column $(10 \times 250 \mathrm{~mm})$ with a linear gradient of acetonitrile $(0-50 \%$ for $20 \mathrm{~min}$ ) containing $0.1 \%$ trifluoroacetic acid at a flow rate of $1 \mathrm{ml} / \mathrm{min}$. The absorbance of eluent was monitored at $280 \mathrm{~nm}$.

DU-145 cell culture. DU-145 cells were cultured in F-12 medium, supplemented with $10 \%$ FBS (v/v), 2 mM glutamine, $100 \mathrm{IU} / \mathrm{ml}$ penicillin and $100 \mathrm{IU} / \mathrm{ml}$ streptomycin. Cultures were maintained in a humidified incubator at $37^{\circ} \mathrm{C}$, with $5 \%$ $\mathrm{CO}_{2}$ and $95 \%$ air.
Antiproliferative activity using an MTT assay. The cytotoxicity of RPOI-1 against the DU-145 cells was assessed using a colorimetric MTT assay. DU-145 cells were seeded $\left(1 \times 10^{5}\right.$ cells $\left./ \mathrm{ml}\right)$ together with various concentrations of the RPOI-1 sample $(10,15,20,25$ and $30 \mathrm{mg} / \mathrm{ml})$ and incubated for up to 24,48 or $72 \mathrm{~h}$ prior to MTT treatment. A stock solution of $50 \mu \mathrm{l}$ of $2 \mathrm{mg} / \mathrm{ml}$ MTT in phosphate-buffered saline (PBS) was added to each well to achieve a total reaction volume of $250 \mu 1$. Following $5 \mathrm{~h}$ incubation, the formazan crystals in each well were dissolved in dimethyl sulfoxide. The quantity of purple formazan was assessed by measuring the absorbance at $490 \mathrm{~nm}$ using an enzyme-linked immunosorbent assay reader (Thermo Multiskan Spectrum; Thermo Electron Corporation, Dreieich, Germany).

Morphological analyses. DU-145 cells in the exponential growth phase were plated at $1 \times 10^{4}$ cells/well in 6 -well plates. Following $24 \mathrm{~h}$ growth, cells were treated with RPOI-1 at 10, 20 or $30 \mathrm{mg} / \mathrm{ml}$ for $24 \mathrm{~h}$. At the end of the treatment, the effect of RPOI-1 on the morphology of the DU-145 cells was assessed by the inverted and phase-contrast microscope (Olympus Corporation, Tokyo, Japan) at x200 magnification.

Annexin V-FITC/propidium iodide (PI) double-staining analysis. Annexin V-FITC/PI double-staining analysis was used to evaluate the induction of apoptosis in cancer cells by RPOI-1. Exposed phosphatidylserine on the outside of apoptotic cells was determined using the Annexin V-FITC Apoptosis kit. To detect the early and late stages of apoptosis, as well as necrosis induced by RPOI-1, the DU-145 cells were plated at a density of $1 \times 10^{5}$ cells/well in 6-well plates and incubated for $24 \mathrm{~h}$ at $37^{\circ} \mathrm{C}$ in $5 \% \mathrm{CO}_{2}$. Cells were harvested by centrifugation at $4,000 \mathrm{x}$ g for 7 ; they were then washed with ice-cold PBS twice and stained with $10 \mu \mathrm{l}$ PI and $5 \mu \mathrm{l}$ Annexin V-FITC at room temperature for $15 \mathrm{~min}$ in darkness. Annexin V-FITC and PI emissions were detected in the FL1 and FL2 channels of a FACSCalibur flow cytometer (Becton-Dickinson, San Jose, CA, USA). The distribution percentages of normal cells, necrotic cells, and cells in the early and late stages of apoptosis were calculated by Cell-Quest software (BD Biosciences, Franklin Lakes, NJ, USA).

Cell cycle analysis. Flow cytometric analyses were conducted in order to determine the proportion of apoptotic sub-G1 hypodiploid cells. DU-145 cells were placed in 6-well plates at a concentration of $1 \times 10^{5}$ cells $/ \mathrm{ml}$ for $16 \mathrm{~h}$ and treated with 10 or $30 \mathrm{mg} / \mathrm{ml}$ RPOI-1. Following incubation for $24 \mathrm{~h}$, the cells were harvested, as previously described, at the indicated times and fixed for $30 \mathrm{~min}$ in $1 \mathrm{ml}$ of $70 \%$ ethanol at $4^{\circ} \mathrm{C}$. The cells were then washed twice with PBS and incubated for $30 \mathrm{~min}$ in darkness in $1 \mathrm{ml}$ PBS containing $100 \mu \mathrm{g}$ PI and $100 \mu \mathrm{g}$ RNase A (Sigma, St. Louis, MO, USA), at $37^{\circ} \mathrm{C}$. Flow cytometric analysis was conducted using a FACS Calibur flow cytometer (Becton Dickinson). Effects on the cell cycle were determined by measuring changes in the percentage of cell distribution at each phase of the cell cycle and were assessed by histograms generated by the Cell Quest and Mod-Fit computer programs (Verity Software House, Topsham, ME, USA). 


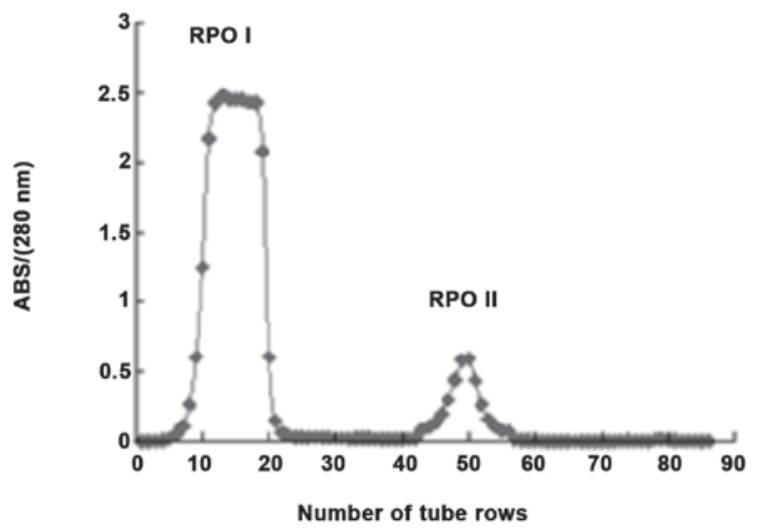

Figure 1. Diethyaminoethyl-sepharose fast flow chromatography of the antimicrobial peptide isolated from Ruditapes philippinarum.

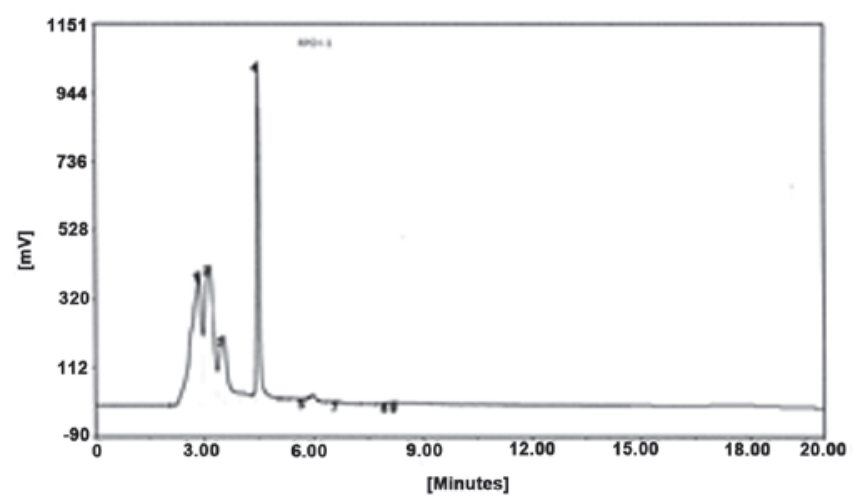

Figure 2. Reverse-phase high performance liquid chromatography of the oligopeptide isolated from Ruditapes philippinarum.

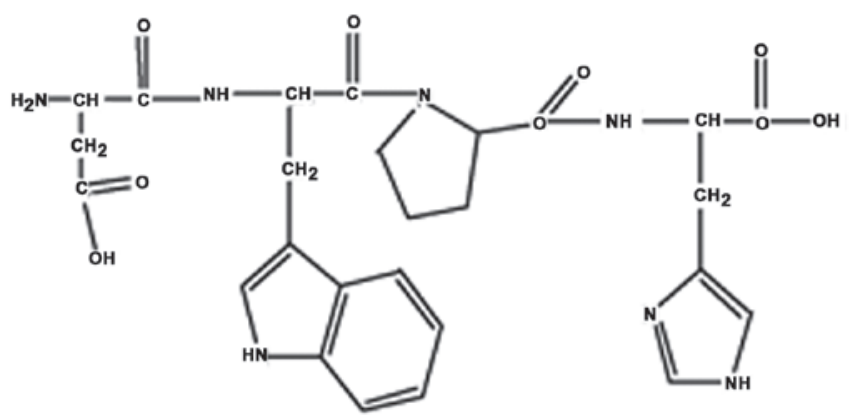

Figure 3. Amino-acid backbone of Ruditapes philippinarum oligopeptide.

Statistical analysis. Data are expressed as the mean \pm standard deviation. Significance was determined by an unpaired Student's t-test using SPSS 16.0 software (SPSS, Inc., Chicago, IL, USA). $\mathrm{P}<0.05$ was considered to indicate a statistically significant difference.

\section{Results and Discussion}

The lyophilized trypsin digestion was dissolved in Tris/HCl buffer $(0.05 \mathrm{mmol} / \mathrm{l}, \mathrm{pH} 7.14)$ and loaded onto a DEAE-Sepharose FF column with a linear gradient of $\mathrm{NaCl}$ $(0.01 \mathrm{~mol} / \mathrm{l})$. As shown in Fig. 1, the elution peaks were

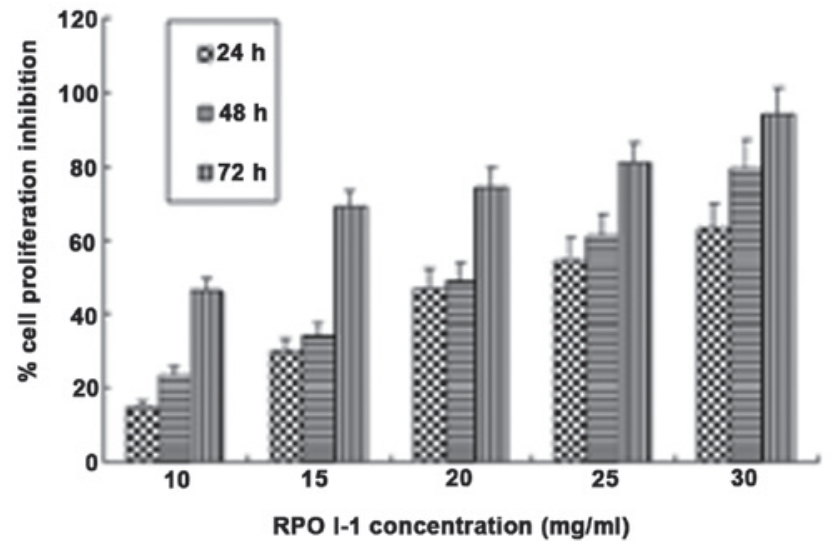

Figure 4. Inhibition of proliferation of RPOI-1-treated DU-145 cells. DU-145 cells were treated with $10,15,20,25$ or $30 \mathrm{mg} / \mathrm{ml}$ RPOI-1. Cell proliferation was measured using a 3-(4,5-dimethylthiazol-2-yl)-5,5-diphenyltetrazolium bromide assay at 24,48 and $72 \mathrm{~h}$ after RPOI-1 treatment. Data are presented as the mean \pm standard deviation. Each experiment was performed in triplicate $(\mathrm{n}=3)$. RPOI-1, Ruditapes philippinarum oligopeptide.

monitored at $280 \mathrm{~nm}$, and two major fractions (RPOI and RPOII) were identified. Due to the higher anticancer activity of RPOI, this molecule was further separated using reverse-phase HPLC. As shown in Fig. 2, peak 4 was collected and termed RPOI-1. Its sequence was identified as N-Asp-Trp-Pro-His, with a molecular mass of $607.6 \mathrm{kDa}$. The amino-acid backbone of RPOI-1 is shown in Fig. 3.

Evaluation of RPOI-1 for potential anticancer activity on DU-145 cells was conducted by investigating its inhibitory effects on cell growth using an MTT assay. As shown in Fig. 4, RPOI-1 inhibited DU-145 cell proliferation in a dose- and time-dependent manner. Furthermore, RPOI-1 exhibited $>90 \%$ cell proliferation inhibition at a concentration of $30 \mathrm{mg} / \mathrm{ml}$ following $72 \mathrm{~h}$ treatment.

Morphological observation of apoptotic cells by fluorescence microscopy using acridine orange (AO) staining is a well-established biological assay for detecting apoptotic cells.

Apoptosis, also termed programmed cell death, is characterized by typical cellular morphology and biochemical features, including cell shrinkage, cytoplasm vacuolization, chromatin condensation, DNA fragmentation and ultimately cellular breakdown into apoptotic bodies (11).

To clarify whether the cell death of RPOI- 1 treated cells occurred via induction of apoptosis, the presence of apoptotic features in the treated cells was confirmed by double $\mathrm{AO} /$ ethidium bromide staining.

As a control, DU-145 cells were cultured in complete media and stained with AO/EB (Fig. 5A). Viable cells appear homogeneous, with bright green nuclei and an intact structure, as shown in Fig. 5A. As displayed in Fig. 5B, early apoptotic cells contained green nuclei, but perinuclear chromatin condensation was also visible as bright green patches or fragments. Fig. 5C and D show cells in later stages of apoptosis, which contain orange-red nuclei with condensed or fragmented chromatin, and necrotic cells, which contained a homogeneous orange-red nuclei with an intact structure.

These changes indicated that RPOI-1 may induce DU-145 cell apoptosis. More apoptotic cells in later stages of apoptosis were observed with higher concentrations of RPOI-1. 
A

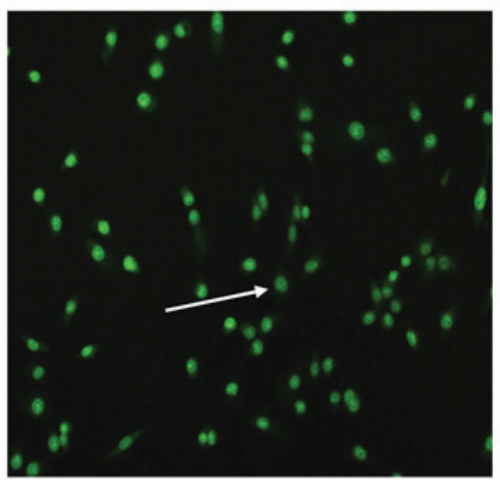

C

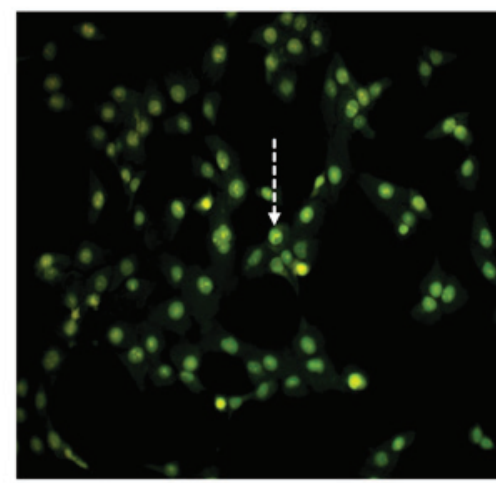

B

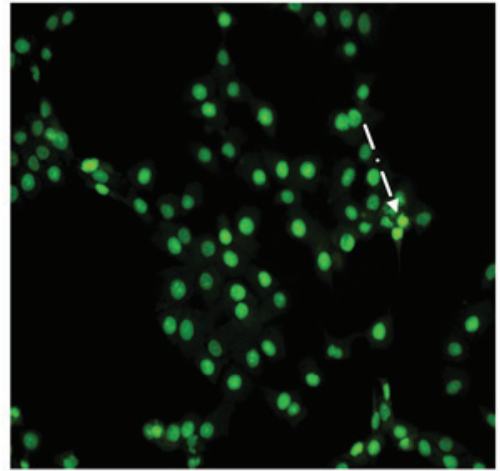

D

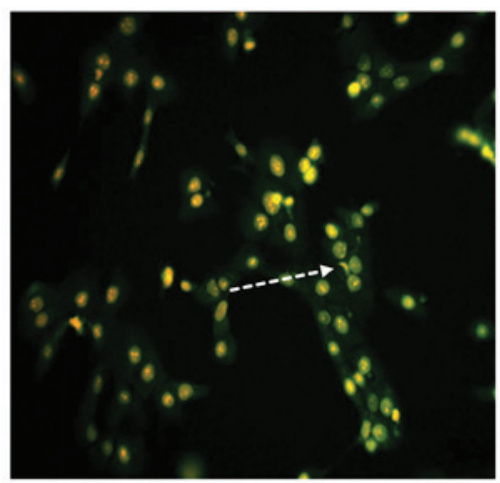

Figure 5. Morphological observation with acridine orange/ethidium bromide staining. DU-145 cells were treated with Ruditapes philippinarum oligopeptide at $5 \mathrm{mg} / \mathrm{ml}$, (B); $10 \mathrm{mg} / \mathrm{ml}$, (C); and $15 \mathrm{mg} / \mathrm{ml}$, (D). (A) Representative image of DU-145 cells without treatment. Solid arrows indicate viable cells; dashed arrows indicate early apoptotic cells; and dash-dot arrows indicate late apoptotic cells. Each experiment was performed in triplicate and similar morphologic features were observed in each repetition. Original magnification, x200.

A
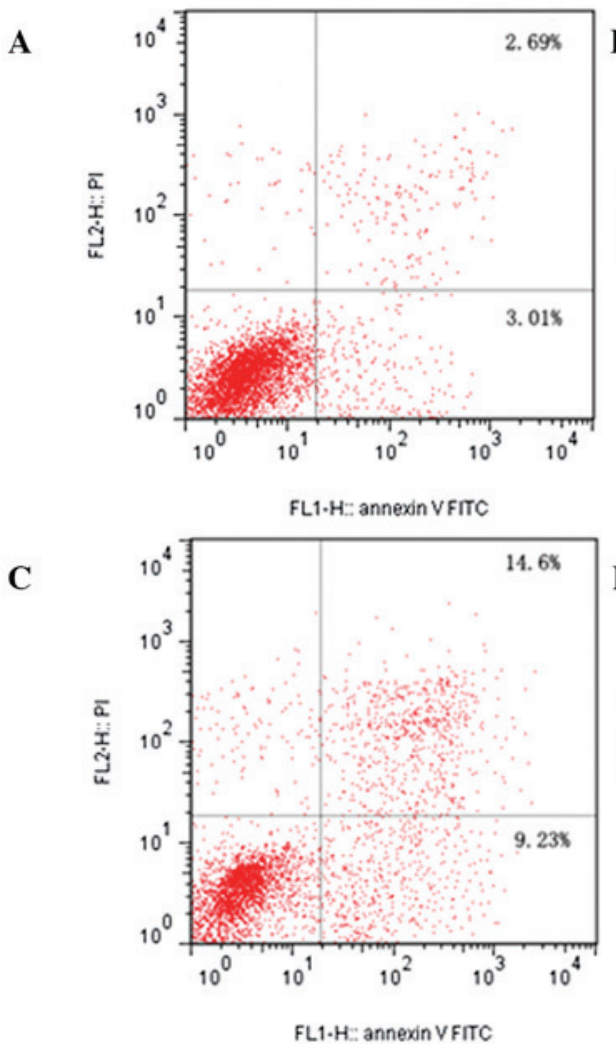
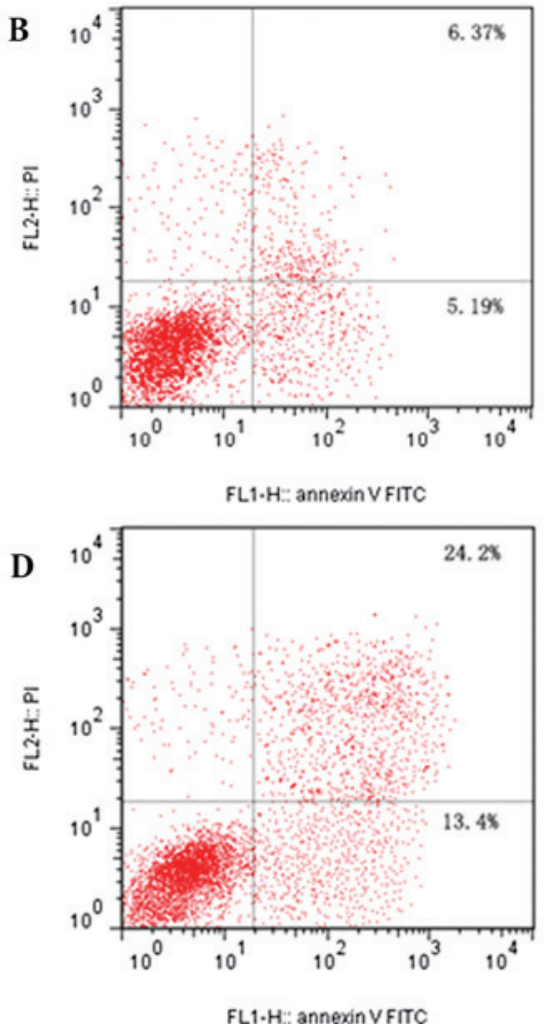

Figure 6. Flow cytometric analysis of DU-145 cells by double-labeling with Annexin V-FITC and PI. Lower left quadrant, live cells; upper left quadrant, early apoptotic cells; lower right quadrant, necrotic cells; and upper right quadrant, late apoptotic cells. (A) control cells; (B) RPOI-1 (5 mg/ml); (C) RPOI-1 (10 mg/ml); and (D) RPOI-1 (15 mg/ml). Percentages of early apoptotic cells were $3.01 \pm 0.75 \%, 5.19 \pm 1.29 \%, 9.23 \pm 1.02 \%$, and $13.40 \pm 2.64 \%$, respectively. One representative fluorescence-activated cell sorting assay of three independent experiments is shown for each group. FITC, fluorescein isothiocyanate; PI, propidium iodide; RPOI-1, Ruditapes philippinarum oligopeptide. 
Table I. Percentage of DU-145 cells in sub-G1, G0/G1, S and G2/M phases.

\begin{tabular}{lcrrr}
\hline & \multicolumn{4}{c}{ DU-145 cells (\%) } \\
\cline { 2 - 5 } RPOI-1 $(\mathrm{mg} / \mathrm{ml})$ & Sub-G1 & $\mathrm{G} 0 / \mathrm{G} 1$ & $\mathrm{~S}$ & $\mathrm{G} 2 / \mathrm{M}$ \\
\hline 0 & $0.66 \pm 0.61$ & $48.82 \pm 1.34$ & $19.33 \pm 3.15$ & $31.10 \pm 1.67$ \\
10 & $3.67 \pm 0.27^{\mathrm{a}}$ & $48.80 \pm 3.21$ & $10.40 \pm 1.04^{\mathrm{a}}$ & $40.37 \pm 3.33^{\mathrm{a}}$ \\
30 & $5.74 \pm 0.59^{\mathrm{a}}$ & $45.63 \pm 2.12$ & $6.83 \pm 1.18^{\mathrm{a}}$ & $48.67 \pm 2.40^{\mathrm{a}}$ \\
\hline
\end{tabular}

Data represent the mean \pm standard deviation of three independent experiments. ${ }^{\mathrm{P}}<0.05$, compared with control. RPOI- 1 , Ruditapes philippinarum oligopeptides.
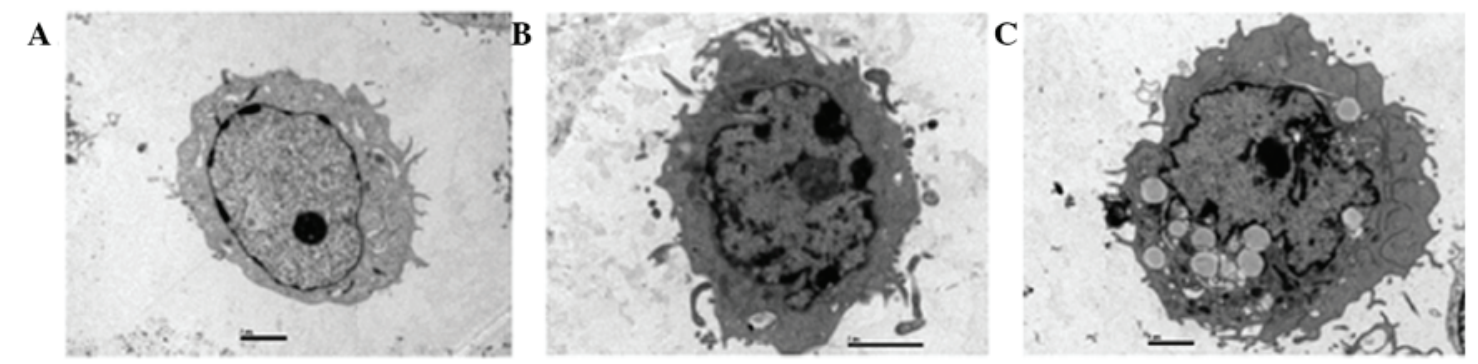

Figure 7. TEM micrographs of DU-145 cells. (A) Without RPOI-1, (B) with $10 \mathrm{mg} / \mathrm{ml}$ RPOI-1 and (C) with $30 \mathrm{mg} / \mathrm{ml}$ RPOI-1 treatment for $48 \mathrm{~h}$. All images shown are at x3,700 magnification. (A) Shows a typical ultrastructure, characterized by a well-preserved plasma membrane. Abundant microvilli are observed on the surface and the nucleus contains a nucleolus and euchromatin. (B) and (C) show the early stages of apoptosis. The majority of organelles in the cytoplasm have lost a number of their individual characteristics, and few microvilli are observed on the cell surface. The cytoplasm contains large lipid droplets and has an increased frequency of larger lysosomes. RPOI-1, Ruditapes philippinarum oligopeptide.
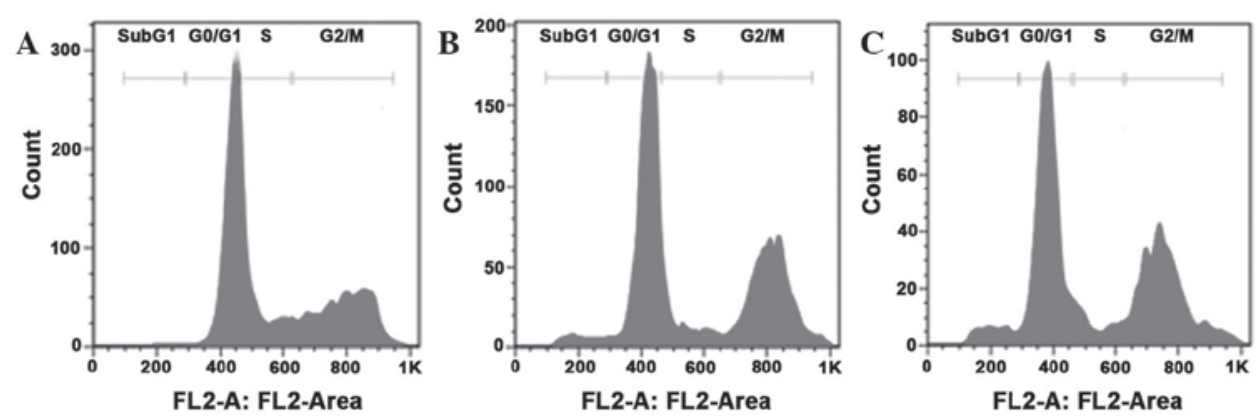

Figure 8. Effect of Ruditapes philippinarum oligopeptide on cell cycle progression in DU-145 cell lines. (A) Untreated controls. Cells were exposed at concentrations of (B) $10 \mathrm{mg} / \mathrm{ml}$ and (C) $30 \mathrm{mg} / \mathrm{ml}$ for $24 \mathrm{~h}$. Flow cytometry was conducted to define the cell cycle distribution in comparison with controls. The cell cycle profile is representative of three independent experiments.

In order to quantify the proportion of cells that had undergone apoptosis, DU-145 cells were treated with RPOI-1 for $24 \mathrm{~h}$, followed by simultaneous staining with Annexin V-FITC and PI and analyzed by BD FACSCalibur flow cytometry. Annexin V-FITC/PI double-staining analysis demonstrated that the treatment with RPOI-1 decreased the number of healthy DU-145 cells in a dose-dependent manner. As shown in Fig. 6, the number of apoptotic cells in the early and late stages of apoptosis increased in a dose-dependent manner from 3.01 to $13.40 \%$ and from 2.69 to $24.20 \%$ at the highest dose, respectively.

Transmission electron microscopy is the preferred method for morphological observation by which to clearly differentiate nuclei and organelles. It was used to confirm apoptosis in DU-145 cells in this study. As shown in Fig. 7A, there were no typical morphological changes of apoptosis observed in control cells. However, when cells were exposed to RPOI-1 for $48 \mathrm{~h}$, characteristic apoptotic morphological changes were observed, as shown in Fig. 7B and C. These results demonstrate that RPOI-1 induced apoptosis in DU-145 cells. Following $48 \mathrm{~h}$ of incubation with $10 \mathrm{mg} / \mathrm{ml}$ RPOI-1, the nuclei were shrunken, irregularly shaped and chromatin was highly condensed at the nuclear periphery. Furthermore, apoptotic bodies were observed in the cytoplasm following treatment with $30 \mathrm{mg} / \mathrm{ml}$ RPOI-1 for $48 \mathrm{~h}$. In addition, overall cell size was reduced and the nuclei were shrunken. These findings were highly suggestive of apoptosis in those cells exposed to RPOI-1. However, characteristics of necrotic change, such as swelling of cytoplasm or intracytoplasmic organelles, were not observed. 
Cancer is a disease state characterized by disordered proliferation and the inhibition of apoptosis. The uncontrolled cellular growth and proliferation that distinguishes cancer cells from normal cells are key processes in carcinogenesis (12). The inhibition of proliferation and induction of apoptosis are efficient methods by which to treat tumors (13). For example, a number of anticancer agents induce cell death by interfering with processes in the cell cycle (14) and others lead to cell death by increasing apoptosis (15).

In order to quantify the induction of apoptosis by RPOI-1 treatment, flow cytometric analysis was conducted. As shown in Fig. 8, the percentage of cells in the sub-G1 phase was $0.66 \%$ in the control group. However, as shown in Fig. 7 , RPOI-1 treatment in the DU-145 cells at concentrations of 10 or $30 \mathrm{mg} / \mathrm{ml}$ induced a dose-dependent increase in the proportion of cells in different phases of the cell cycle, as reflected in the change in the percentage of cells in the sub-G1 phase (3.67 and $5.74 \%$, respectively). Table I shows that there was a significant increase from $0.66 \pm 0.61$ to $5.74 \pm 0.59 \%$ in the sub-G1 phase and from $31.10 \pm 1.67$ to $48.67 \pm 2.40 \%$ in the $\mathrm{G} 2 / \mathrm{M}$ phase in DU-145 cells treated with $30 \mathrm{mg} / \mathrm{ml}$ RPOI-1. These results demonstrate that RPOI-1 induced G2 phase arrest and apoptosis in DU-145 cells.

In conclusion, RPOI-1 had a toxic effect on DU-145 cells and typical apoptotic morphological changes were observed with AO/EB staining, FCM analysis and TEM. The present study demonstrated that RPOI-1 inhibited DU-145 cell proliferation through induction of the apoptotic pathway and that Ruditapes philippinarum may possess anticancer properties. To the best of our knowledge, these findings demonstrate for the first time the anticancer potential of Ruditapes philippinarum. This evidence for biological activity in the Ruditapes philippinarum extract indicates that its consumption may be beneficial to health. In addition, the findings of this study may increase awareness regarding the potential anticancer properties of RPOI-1 and aid future developments in anticancer therapeutics on an industrial scale.

\section{Acknowledgements}

This study was supported by the General Projects of National Natural Science Foundation (grant no. 81273429), the Major Project of Zhejiang Provincial Science and Technology Office (grant no. 2010C13009) and the Natural Science Foundation of Zhejiang Province (grant nos. Y2100805, Y3100129, LY12C20008 and LY12C20005).

\section{References}

1. Goel S, Mita AC, Mita M, et al: A phase I study of eribulin mesylate (E7389), a mechanistically novel inhibitor of microtubule dynamics, in patients with advanced solid malignancies. Clin Cancer Res 15: 4207-4212, 2009.

2. Hadaschik BA, Adomat H, Fazli L, et al: Intravesical chemotherapy of high-grade bladder cancer with HTI-286, a synthetic analogue of the marine sponge product hemiasterlin. Clin Cancer Res 14: 1510-1518, 2008.

3. Den Brok MW, Nuijen B, Meijer DM, Millán E, Manada C and Beijnen JH: Pharmaceutical development of a parenteral lyophilised formulation of the investigational anticancer agent ES-285.HCl. PDA J Pharm Sci Technol 59: 246-257, 2005.

4. Garg V, Zhang W, Gidwani P, Kim M and Kolb EA: Preclinical analysis of tasidotin $\mathrm{HCl}$ in Ewing's sarcoma, rhabdomyosarcoma, synovial sarcoma, and osteosarcoma. Clin Cancer Res 13: 5446-5454, 2007

5. Huang F, Yang Z, Yu D, Wang J, Li R and Ding G: Sepia ink oligopeptide induces apoptosis in prostate cancer cell lines via caspase-3 activation and elevation of Bax/Bcl-2 ratio. Mar Drugs 10: 2153-2165, 2012.

6. Sánchez C,MendozaP,Contreras HR, et al: Expression of multidrug resistance proteins in prostate cancer is related with cell sensitivity to chemotherapeutic drugs. Prostate 69: 1448-1459, 2009.

7. Nehmé A, Varadarajan P, Sellakumar G, et al: Modulation of docetaxel-induced apoptosis and cell cycle arrest by all- trans retinoic acid in prostate cancer cells. Br J Cancer 84: 1571-1576, 2001.

8. Tyagi AK, Singh RP, Agarwal C, Chan DC and Agarwal R: Silibinin strongly synergizes human prostate carcinoma DU145 cells to doxorubicin-induced growth inhibition, G2-M arrest, and apoptosis. Clin Cancer Res 8: 3512-3519, 2002.

9. Dong H, Bai LP, Wong VK, et al: The in vitro structure-related anti-cancer activity of ginsenosides and their derivatives. Molecules 16: 10619-10630, 2011.

10. Sondhi SM, Singh J, Rani R, Gupta PP, Agrawal SK and Saxena AK: Synthesis, anti-inflammatory and anticancer activity evaluation of some novel acridine derivatives. Eur J Med Chem 45: $555-563,2010$.

11. Heo SJ, Kim KN, Yoon WJ, et al: Chromene induces apoptosis via caspase- 3 activation in human leukemia HL-60 cells. Food Chem Toxicol 49: 1998-2004, 2011.

12. Bartek J, Lukas C and Lukas J: Checking on DNA damage in S phase. Nat Rev Mol Cell Biol 5: 792-804, 2004.

13. KinlochRA,TreherneJM,FurnessLMandHajimohamadrezaI:The pharmacology of apoptosis. Trends Pharmacol Sci 20: 35-42, 1999.

14. Dirsch VM, Antlsperger DS, Hentze H and Vollmar AM: Ajoene, an experimental anti-leukemic drug: mechanism of cell death. Leukemia 16: 74-83, 2002.

15. Gamet-Payrastre L,Li P,Lumeau S, et al: Sulforaphane, a naturally occurring isothiocyanate, induces cell cycle arrest and apoptosis in HT29 human colon cancer cells. Cancer Res 60: 1426-1433, 2000. 